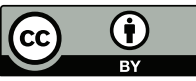

DOI 10.4467/12332135KRA.21.003.14682

\title{
Karolina Zięba
}

ORCID: 0000-0002-9569-002

Archiwum Narodowe w Krakowie

\section{Działalność Bronisława Piłsudskiego na rzecz ludności Spisza i Orawy. Na marginesie listu do Bolesława Wysłoucha}

Pamięci prof. Czesława Robotyckiego (1944-2014)

\section{The activity of Bronisław Pilsudski for the people of Spisz and Orawa. Based on a letter to Bolesław Wyslouch}

In memory of Prof. Czesław Robotycki (1944-2014)

\begin{abstract}
SŁOWA KLUCZOWE: Bronisław Piłsudski, Bolesław Wysłouch, Jan Bednarski, Spisz, Orawa, Związek Przyjaciół Polskiego Ludu Tatrzańskiego, Sekcja Ludoznawcza Towarzystwa Tatrzańskiego, świadomość narodowa

KEY WORDS: Bronisław Piłsudski, Bolesław Wysłouch, Jan Bednarski, Spisz, Orawa, Friends of Polish Tatra Highlanders Association, Tatra Society's Ethnographic Section, national identity
\end{abstract}

\begin{abstract}
ABSTRAKT: Bronisław Piłsudski (1866-1918) jest znany na świecie przede wszystkim jako badacz ludów Dalekiego Wschodu - informacje o jego aktywności w Galicji oraz na Spiszu i Orawie są mniej powszechne. Odnaleziony w aktach Związku Przyjaciół Polskiego Ludu Tatrzańskiego, napisany w 1912 r. list do Bolesława Wysłoucha (1855-1937), stanowi jeszcze jedno świadectwo wszechstronności jego działań również na gruncie polskim. Po powrocie z zesłania B. Piłsudski zaangażował się w działalność muzealniczą i społeczną w Galicji. Utrzymywał kontakty z polską inteligencją pracującą na rzecz zachowania tożsamości narodowej pod zaborami. Do tej grupy należał również B. Wysłouch - redaktor „Kuriera Lwowskiego”. Prezentowany artykuł naświetla kontekst akcji uświadomienia narodowego ludności tzw. „Zapomnianych Kresów”.
\end{abstract}

ABSTRACT: Bronisław Piłsudski (1866-1918) is primarily known in the world for his research work into the peoples of the Far East. There is not so much information about his 
activities in Galicia as well as in Spisz and Orawa. However, a letter written in 1912 to Bolesław Wysłouch (1855-1937), found in the records of the Friends of Polish Tatra Highlanders Association, represents a testimony to his wide-ranging activities on Polish land. After returning from exile, B. Piłsudski was involved in museum and social activities in Galicia. He remained in contact with the Polish intelligentsia, working to maintain national identity during the partitions. This group also included B. Wysłouch - editor of "Kurier Lwowski". The presented article highlights the context of actions to raise awareness of the national identity in the so-called "Forgotten Borderlands".

W 2018 r. cała Polska świętowała stulecie wyzwolenia spod panowania państw zaborczych. Podczas rozmaitych wydarzeń towarzyszących obchodom akcentowano rolę Józefa Piłsudskiego w walce o odzyskanie niepodległości. W maju tego samego roku przypadała także inna okrągła rocznica: stulecie śmierci Bronisława Piłsudskiego - starszego brata Naczelnika Państwa. Obu Piłsudskich łączyła głęboka troska o Polskę, różniły natomiast metody dochodzenia do celu. Najbardziej trafną charakterystyką postawy Bronisława, pacyfisty z przekonania, sprzeciwiającego się wszelkim formom militaryzmu, jest jego odpowiedź na indagacje ze strony Wacława Sieroszewskiego na temat walk Legionów: „Cóż kiedy ja... nie mogę!... Każdy służy jak umie!...". W Wspomniana służba polegała na wspieraniu akcji propagandowej na rzecz Polski oraz próbach (niestety nieudanych) pogodzenia zwaśnionych stronnictw emigracyjnych, by pomimo dzielących je różnic połączyły wysiłki dla odbudowy państwa².

Osoba B. Piłsudskiego przez szereg lat pozostawała zupełnie nieznana w Ojczyźnie, mimo iż za granicą był on już za życia uznanym i cenionym etnografem. Do popularyzacji wiedzy o tej nietuzinkowej postaci w Polsce przyczynili się dopiero organizatorzy międzynarodowych konferencji po-

${ }^{1}$ Wacław Sieroszewski, Bronisław Piłudski urodził się w roku 1866 w Zułowie w pow. święciańskim, zmart w roku 1918 w Paryżu, ,Rocznik Podhalański” 1914-1921, nr 1, s. XXV.

${ }^{2}$ Obszerne informacje na temat działalności B. Piłsudskiego w środowisku emigracyjnym podaje Halina Florkowska-Frančić, Ostatnie lata Bronisława Pitsudskiego 1915-1918 (Szwajcaria-Paryż), [w:] Bronisław Piłsudski (1866-1918). Człowiek - uczony patriota, red. Mieczysław Rokosz [et al.], Zakopane 2003, s. 188, $190 \mathrm{i}$ in. 
święconych życiu i spuściźnie badacza ludów Dalekiego Wschodu³. Ostatniemu kongresowi towarzyszyła wystawa zatytułowana „Ajnowie, górale i Bronisław Piłsudski”, ilustrująca obszary jego etnograficznych zainteresowań badawczych ${ }^{4}$.

Przyczynki do pełnej biografii tego niezwykłego zesłańca pojawiały się już wielokrotnie na łamach czasopism naukowych ${ }^{5}$. Punktem odniesienia dla publikowanego $\mathrm{w}$ aneksie listu jest jego powrót po prawie 15 latach katorgi do pozostającej pod zaborami Polski. W 1887 r. B. Piłsudski został skazany za udział w zamachu na cara Aleksandra III. Pierwotnie orzeczoną karę śmierci zastąpiono wyrokiem wygnania na Sachalin. Pobyt na cieszącej się złą sławą wyspie więzieniu zaowocował etnograficznymi obserwacjami różnych aspektów kultury Niwchów (Gilaków), Oroków i Ajnów. Działając na rzecz edukacji oraz obrony praw ludności tubylczej, wśród której przez wiele lat mieszkał, wpisał się w historię prekursorów nurtu, dziś nazywanego antropologią zaangażowaną ${ }^{6}$.

B. Piłsudski pozostawił po sobie bogatą korespondencję, która została częściowo opublikowana ${ }^{7}$. Ze względu na mnogość kontaktów, jakie utrzy-

${ }^{3}$ Do tej pory odbyły się cztery międzynarodowe konferencje poświęcone B. Piłsudskiemu. Pierwsza z nich, zorganizowana przez Uniwersytet Hokkaido w Sapporo-Nibutani w 1985 r., dotyczyła treści wykonanych przez B. Piłsudskiego nagrań fonograficznych. Sześć lat później Jużnosachalińsk gościł prelegentów konferencji przygotowanej przez Sachalińskie Okręgowe Muzeum Krajoznawcze. Na gruncie polskim (w Krakowie oraz Zakopanem w 1999 r.) miała miejsce trzecia z kolei konferencja poświęcona dziedzictwu naukowemu etnografa. Ostatnie sympozjum odbyło się również w Krakowie z okazji setnej rocznicy śmierci B. Piłsudskiego przypadającej w $2018 \mathrm{r}$.

${ }^{4}$ Prezentowana była w dniach 18 października 2018 - 20 stycznia 2019 r. w Muzeum Sztuki i Techniki Japońskiej Manggha. Kurator ekspozycji dr Anna Król jest równocześnie autorką koncepcji publikacji towarzyszącej wystawie. Zob. Ajnowie, górale i Bronisław Pitsudski, red. Anna Król, Kraków 2018.

${ }^{5}$ Zob. np. Antoni Kuczyński, Bronisław Piłsudski (1866-1918) zesłaniec i badacz kultury ludów Dalekiego Wschodu, „Niepodległość i Pamięć” 2005, 22/2 (50), s. 7-93; J an Staszel, Bronisław Pitsudski i jego związki z Akademia Umiejętności w Krakowie, „Rocznik Biblioteki Naukowej PAU i PAN w Krakowie” 2001, R. 46, s. 7-104.

${ }^{6}$ B. Piłsudski nie był zresztą jedynym polskim badaczem reprezentującym tego typu podejście do eksploracji terenowych - podobną postawę prezentował także Julian Talko-Hryncewicz. Por. Jan Staszel, Listy Bronisława Pitsudskiego do Juliana Talko-Hryncewicza z lat 1909-1914, „Rocznik Biblioteki Naukowej PAU i PAN w Krakowie” 2005, R. 50, s. 194-196.

${ }^{7}$ Publikowana korespondencja obejmuje: lata młodzieńcze, zob. "Dear Father!” a collection of B. Pitsudski's letters, et alii, wyd. Koichi Inoue, Sapporo, 1999; katorgę na 
mywał ze środowiskiem naukowo-artystycznym, opracowania te są jednak dalekie od kompletności. Poszukiwania spuścizny epistolograficznej etnografa trwają nadal, owocując niespodziewanymi odkryciami, o czym świadczy również odnaleziony przez autorkę list skierowany do Bolesława Wysłoucha ${ }^{8}$. Napisany właściwie u szczytu aktywności byłego katorżnika na Podhalu, obrazuje wielokierunkowość jego działań oraz zaangażowanie w sprawę uświadomienia narodowego ludności zamieszkującej Spisz i Orawę.

Na przestrzeni dziejów wspomniane powyżej tereny wielokrotnie włączano lub odłączano od Polski ${ }^{9}$. W dużych miastach wcielonych do Węgier szybko postępowała madziaryzacja. Natomiast tereny wiejskie były właściwie odcięte od wpływów administracji węgierskiej oraz korzyści ${ }^{10}$ wynikających $\mathrm{z}$ asymilacji ${ }^{11}$. Wspólny język i zwyczaje łączyły tamtejszą ludność z góralami beskidzkimi czy podhalańskimi. Dlatego też w spisach ludności uznawano ją za etnicznie polską. Dopiero w 1880 r. rubrykę wykazującą

Sachalinie, zob. Zbigniew Wójcik, Z nieznanej korespondencji zesłańczej Bronisława Piłsudskiego, „Niepodległość i Pamięć” 1996, nr 3/2 (6), s. 153-160; pobyt w Japonii, zob. kolejne artykuły cyklu „Japonica $\mathrm{w}$ archiwaliach po Bronisławie Piłsudskim w Bibliotece PAU i PAN w Krakowie” opracowywanego przez Alfreda F. Majewicza, „Rocznik Biblioteki Naukowej PAU i PAN w Krakowie", passim; trudy odnajdywania się byłego katorżnika w polskich realiach początku XX w., zob. np. J. Staszel, Listy Bronisława Pitsudskiego do Juliana Talko-Hryncewicza..., s. 187-250. Na temat dotychczas nieopublikowanej korespondencji B. Piłsudskiego zob. np. Z. Wójcik, Z nieznanej korespondencji..., s. 154. Spuścizna B. Piłsudskiego nie ogranicza się jedynie do korespondencji. Zachowały się również unikatowe fotografie ludności tubylczej wykonane przez niego podczas zesłania (przechowywane obecnie w Zakładzie Antropologii Instytutu Zoologii i Badań Biomedycznych Uniwersytetu Jagiellońskiego). Na uwagę zasługuje także obszerny dziennik Bronisława z lat młodzieńczych prezentujący losy rodziny Piłsudskich w latach 1882-1885, przechowywany w zbiorach Biblioteki Litewskiej Akademii Nauk im. Wróblewskich w Wilnie.

${ }^{8} \mathrm{O}$ którym dalej.

${ }^{9}$ Zob. Jerzy M. Roszkowski, ,Zapomniane Kresy”. Spisz, Orawa, Czadeckie w świadomości i działaniach Polaków 1895-1925, Nowy Targ 2018, s. 13-24.

${ }^{10}$ Dosadnie na temat korzyści wynikających z konsolidacji z węgierskim społeczeństwem pisze w swoim artykule Edmund Kołodziejczyk, jednocześnie broniąc Słowaków przed oskarżeniami o działalność wynaradawiającą polskich górali. Zob. Edmund Kołodziejczyk, O słowaczeniu i madiaryzacyi, „Świat Słowiański” 1913, R. 9, t. 2, nr 104105, s. 464-474.

${ }^{11}$ Kazimierz Dobrowolski, Powstanie świadomości narodowej u ludu polskiego na Spiszu i Orawie, „Przegląd Współczesny” 1922, R. 1, t. 3, s. 53. 
narodowość polską usunięto, zastępując narodowością słowacką ${ }^{12}$. Chciano w ten sposób zapobiec spodziewanym próbom wpływu na wzrost świadomości narodowej z terenów obecnej Małopolski. Ten krok, paradoksalnie, aktywizował galicyjską opinię publiczną, która do tej pory nie podnosiła kwestii tzw. „kresów południowych”13.

Polska akcja narodowo-oświatowa na Spiszu i Orawie zapoczątkowana na przełomie XIX i XX w. była odpowiedzią na wynaradawiającą politykę władz zaborczych. Do głównych postulatów należało oficjalne uznanie przez Budapeszt polskiej mniejszości narodowej na obszarze górnych Węgier, a także przyznanie jej praw, z których korzystały inne nacje wchodzące w skład imperium. Żądano również utworzenia polskich szkół oraz seminarium duchownego, co zapobiegłoby propagandzie prowadzonej przez księży słowackich. Kwestią budzenia świadomości zajęli się słowianofile skupieni wokół czasopisma „Świat Słowiański”"14 oraz działacze spisko-orawscy z Nowego Targu. Z tymi ostatnimi związany był B. Piłsudski. Zadania, które stawiała sobie grupa nowotarskich ,budzicieli”, to m.in.:

pozyskiwanie dla idei polskości światlejszych jednostek drogą osobistych wpływów, skupianie młodzieży spisko-orawskiej w szkołach polskich, nawiązywanie stosunków towarzyskich między ludem podhalańskim a spisko-orawskim oraz wysyłka prasy polskiej ${ }^{15}$.

Kontakty z kresowianami ograniczały się dotychczas do wymiany handlowej ${ }^{16}$ lub spotkań podczas pielgrzymek do miejsc kultu (popularnością cieszyły się zwłaszcza sanktuaria w Kalwarii Zebrzydowskiej i Ludźmierzu).

${ }^{12}$ Ludność polska miała szybciej ulec słowakizacji ze względu na bliskość etniczną między obydwoma narodami. Następnie planowano poddać madziaryzacji Słowaków, których uznano za prospektywnie łatwiejszy przedmiot wynarodowienia. Na temat słowackich dążeń do zachowania odrębności narodowej w Królestwie Węgierskim zob. Anton Špiesz, Dzieje Słowacji na drodze do uświadomienia narodowego, Bratislava 1992, s. $83-109$.

${ }^{13}$ Pojęcie używane w publicystyce lat 20. XX w. Zob. np. Władysław Semkowicz, Walka o polskie , kresy poludniowe”, „Orli Lot” 1924, R. 5, nr 2-3, s. 18-23.

${ }^{14}$ Organ Towarzystwa Słowiańskiego wydawany w latach 1905-1915 w Krakowie. Jego redaktorem był Feliks Koneczny. Miesięcznik propagował zjednoczenie kulturalno-polityczne Słowian. Na łamach pisma pojawiały się także artykuły dotyczące ludności zamieszkującej Górne Węgry. Postulat działalności na rzecz uświadomienia narodowego nie wyszedł niestety poza teoretyczne ramy.

${ }^{15}$ K. Dobrowolski, Powstanie świadomości..., s. 59.

${ }^{16}$ B. Piłsudski wspomina o tym w publikowanym liście. 
Gdy jesienią 1906 r. B. Piłsudski przyjechał do Krakowa, nie był jeszcze w pełni zorientowany w stosunkach panujących w Galicji. Zaczął nawiązywać znajomości z naukowcami skupionymi wokół Akademii Umiejętności. By poszerzyć spektrum zainteresowań azjatyckimi tubylczymi ludami wiedzą ludoznawczą na temat terenów ojczystych, Jan Rozwadowski $^{17}$ i Kazimierz Nitsch ${ }^{18}$ zasugerowali mu zajęcie się którąś z polskich grup etnograficznych. Pod wpływem lektury książki Stanisława Witkiewicza Na przelęczy. Wrażenia i obrazy z Tatr ${ }^{19}$ postanowił wybrać Podhale jako miejsce przyszłych eksploracji.

B. Piłsudski przebywał na Podhalu stale (z niewielkimi przerwami) od 1911 r. Wcześniej gościł tu na krótko w celach zdrowotnych ${ }^{20}$. Przyjechał do Zakopanego $^{21}$ na zaproszenie hrabiego Władysława Zamoyskiego ${ }^{22}$ - arystokraty o duszy społecznika - który walnie przyczynił się do rozwoju Podtatrza. Posiadanie własnego lokum ${ }^{23}$ umożliwiło Bronisławowi kontynuację opracowywania materiałów zebranych wśród autochtonicznych mieszkańców wyspy Hokkaido. Pokłosiem tej pracy stała się - przygotowywana

${ }^{17}$ Jan Michał Rozwadowski (1867-1935), językoznawca, profesor Uniwersytetu Jagiellońskiego, członek Akademii Umiejętności, pierwszy prezes Polskiego Towarzystwa Językoznawczego. Zainteresowany głównie językoznawstwem indoeuropejskim, nie ograniczył się do własnej dziedziny, wspomagając B. Piłsudskiego podczas pracy nad materiałami pozyskanymi na Hokkaido. Zob. Stanisław Urbańczyk, Jan Michał Rozwadowski, [w:] PSB, t. 32, Kraków 1989-199, s. 406-409.

${ }^{18}$ Kazimierz Nitsch (1874-1958), językoznawca, dialektolog, prezes Polskiej Akademii Umiejętności w latach 1946-1952; wraz z J. M. Rozwadowskim i Janem Łosiem założył w 1920 r. Towarzystwo Miłośników Języka Polskiego. Poświęcił B. Piłsudskiemu obszerne wspomnienie w swojej książce, zob. Kazimierz Nits ch, Ze wspomnién językoznawcy, Warszawa 1960, s. 210-216. Więcej na temat K. Nitscha zob. Stanisław Urbańczyk, Kazimierz Nitsch, [w:] PSB, t. 23, Kraków 1978, s. 145-150.

${ }^{19}$ Książka została po raz pierwszy wydana w Warszawie w 1891 r. nakładem wydawnictwa Gebethner i Wolff.

${ }^{20}$ Jego pierwsze kontakty z Zakopanem datują się na rok 1906.

${ }^{21}$ Dokładnie do Kuźnic. Szerzej na temat pobytu Bronisława w Zakopanem zob. Lesław Da11, Zakopiańskie lata Bronisława Piłsudskiego (1906-1914), [w:] Józef Piłsudski w Zakopanem w latach 1901-1922, Kraków 2019, s. 33-47.

${ }^{22}$ Władysław Zamoyski (1853-1924), właściciel dóbr kórnickich, działacz społeczny zaangażowany m.in. w spór o Morskie Oko; fundator Zakładów Kórnickich. Jego matka, Jadwiga Zamoyska z Działyńskich (1831-1923) założyła Szkołę Domowej Pracy Kobiet, przeniesioną ostatecznie do Kuźnic, gdzie przez pewien czas gościł B. Piłsudski.

${ }^{23}$ Początkowo mieszkał w pokoju gościnnym Szkoły Domowej Pracy Kobiet, w budynku zwanym Mydlarnią, następnie przeniósł się do willi Korniłowiczówka na Bystrem. 
do druku wspólnie z J. M. Rozwadowskim - książka Materiały do języka i folkloru Ajnów ${ }^{24}$, opublikowana w języku angielskim w 1912 r. nakładem Akademii Umiejętności.

Dzięki inicjatywie B. Piłsudskiego powstała Sekcja Ludoznawcza Towarzystwa Tatrzańskiego (dalej: SLTT). Pierwsze zebranie odbyło się w Zakopanem w willi „Tatry” 11 listopada 1911 r. Przewodniczył mu profesor Jan Gwalbert Pawlikowski ${ }^{25}$, znawca Podhala, późniejszy redaktor rocznika „Wierchy”. Decyzją zawiązanego wówczas komitetu wpisano nowy oddział w ramy Towarzystwa Tatrzańskiego ${ }^{26}$. Na kolejnym posiedzeniu B. Piłsudski - jako główny pomysłodawca - przedstawił program pracy sekcji. Zebranie organizacyjne odbyło się ostatecznie 25 listopada tego samego roku. Przewodniczącym został wybrany B. Piłsudski ${ }^{27}$, jego zastępcą Wojciech Brzega $^{28}$. Za cel nadrzędny postawiono sobie ,badanie wszechstronne ludu podhalskiego [!] i w ogóle karpackiego, rozpowszechnianie zebranych o nim wiadomości, oraz ochronę godnych zachowania jego odrębnych cech"29. Zadania, jakie wówczas wyznaczono do realizacji, polegały na: prowadzeniu

${ }^{24}$ Bronisław Piłsudski, Materials for the Study of the Ainu Language and Folklore, Cracow 1912.

${ }^{25}$ Jan Gwalbert Pawlikowski (1860-1939), publicysta, taternik, zasłużony członek Towarzystwa Tatrzańskiego; pionier w zakresie ochrony przyrody w Polsce.

${ }^{26}$ Towarzystwo Tatrzańskie (po wielokrotnych zmianach nazwy obecnie Polskie Towarzystwo Turystyczno-Krajoznawcze PTTK) - pierwsze w Polsce towarzystwo o profilu turystyczno-krajoznawczym zajmujące się ochroną przyrody, upowszechnianiem wiedzy o górach, popularyzacją przewodnictwa górskiego etc.; zainicjowane m.in. przez Tytusa Chałubińskiego w 1873 r. (statut oficjalnie zatwierdzono w 1874 r.). Przy Towarzystwie działały sekcje: Sekcja Turystyczna (1903-1935), Zakopiański Oddział Narciarzy, przekształcony w Sekcję Narciarską (1907-1950), Sekcja Przyrodnicza (1910-1919), Sekcja Ludoznawcza (1911-1914), Sekcja Ochrony Tatr (1912-1930), Sekcja Przyjaciół Zakopanego (1912-1914). Organem TT w latach 1876-1920 był „Pamiętnik Towarzystwa Tatrzańskiego”, następnie „Wierchy” (1923-1949).

${ }^{27}$ Pierwotny skład personalny podany jest w pierwszym sprawozdaniu Sekcji. Zob. Sprawozdanie Sekcyi Ludoznawczej Tow. Tatrzańskiego za czas od 25 listopada 1911 do 31 grudnia 1912 roku, „Pamiętnik Towarzystwa Tatrzańskiego” 1913, t. 34, s. XLIV-XLV.

${ }^{28}$ Wojciech Brzega (1872-1941), pochodzący z Zakopanego rzeźbiarz, snycerz, działacz społeczny. Przyczynił się do rozpowszechnienia stylu zakopiańskiego. Autor publikacji dotyczących górali tatrzańskich, zob. Zofia Radwańska-Paryska, Witold Henryk Paryski, Encyklopedia tatrzańska, Warszawa 1973, s. 51.

${ }^{29}$ Cyt. za: ,, Kochany Wujaszku...” Listy Bronisława Pitsudskiego do Stanisława Witkiewicza, oprac. naukowe Antoni Kuczyński, Zakopane 2016, s. 147. 
badań terenowych według gotowych kwestionariuszy ${ }^{30}$, gromadzeniu zbiorów bibliotecznych, wyszukiwaniu wytworów kultury materialnej, które mogłyby zasilić ekspozycję etnograficzną Muzeum Tatrzańskiego, urządzaniu wycieczek krajoznawczych oraz organizowaniu bezpłatnych odczytów popularyzujących ludoznawstwo.

Za niezbędną uznano współpracę z innymi instytucjami zaangażowanymi w życie Podtatrza - przede wszystkim z Towarzystwem Muzeum im. Tytusa Chałubińskiego w Zakopanem ${ }^{31}$. Członkowie SLTT podjęli się zewidencjonowania kolekcji, uporządkowali również zbiory biblioteczne Muzeum, wykazując konieczne do uzupełnienia braki. Bronisław zainicjował gromadzenie wytworów kultury ludowej w sposób celowy, zgodnie z metodologią inspirowaną jego licznymi zagranicznymi podróżami, podczas których zwiedzał muzea etnograficzne.

Dotychczas bowiem na górali Podhala i ich kulturę patrzono w sposób romantyczny i sentymentalny. [...] Liczni kolekcjonerzy zbierali „piękne” wytwory miejscowej sztuki ludowej, które miały być dowodem wyjątkowej kultury góralskiego ludu i zachowanych „prapolskich” korzeni ${ }^{32}$.

Dla pozyskania nowych eksponatów Sekcja Ludoznawcza rozpoczęła eksploracje terenowe. Badaczom doskwierał brak funduszy, bowiem większość przedmiotów musieli nabywać w drodze kupna. Hanna Błaszczyk-Żurowska wylicza, że Muzeum pozyskało 168 eksponatów etnograficznych dzięki zaangażowaniu członków Sekcji ${ }^{33}$. „Piłsudski, przyjeżdżając na Podhale, był już znanym w świecie etnografem posiadającym wiedzę i doświadczenie muzealne. Ze znawstwem podchodził do zbierania [...] okazów etnograficznych i w tej dziedzinie służył pomocą innym"34. Poprzez usystematyzowanie sposobów gromadzenia do kolekcji trafiły nie tylko

${ }^{30}$ Głównie na podstawie kwestionariusza badań etnograficznych opracowanego przez antropologa Izydora Kopernickiego.

${ }^{31}$ Bronisław Piłsudski był brany pod uwagę jako kandydat na stanowisko prezesa Zarządu Towarzystwa Muzeum Tatrzańskiego, pomysł ostatecznie nie doszedł do skutku. Zob. Zbigniew Wójcik, O Borysie Wigilewie (komentarz do listu do Mieczysława Limanowskiego), „Rocznik Podhalański” 1997, t. 7, s. 277-279.

${ }^{32}$ Hanna Błaszczyk-Żurowska, Działalność kolekcjonerska Bronisława Pitsudskiego w Zakopanem, „Literatura Ludowa” 1999, R. 43, nr 4-5, s. 137.

${ }^{33}$ Ibidem, s. 138.

${ }^{34}$ Anna Kozak, Zakopiańska kolekcja Bronisława Pitsudskiego, [w:] Ajnowie, górale i Bronisław Piłsudski, red. Anna Król, Kraków 2018, s. 179. 
obiekty cenne pod względem estetycznym, takie jak ceramika czy obrazki na szkle, ale także przedmioty użytkowe, których wartość nie była dotąd należycie doceniana. B. Piłsudski pragnął udokumentować wszelkie przejawy materialne kultury Podhala, ponieważ rzemiosło ludowe na tych terenach powoli zanikało - zastępowały je masowo produkowane wyroby fabryczne. Poza powiększaniem kolekcji Muzeum członkowie SLTT zapisywali pieśni, elementy gwary podhalańskiej, przysłowia. Uczestniczyli ponadto w obrzędach, tworząc na tej podstawie ich opisy.

Poza oficjalnymi członkami SLTT B. Piłsudski werbował tzw. współpracowników prowadzących eksploracje w swoim miejscu zamieszkania. Przede wszystkim dla nich zorganizowano odczyty dotyczące metodologii badań terenowych ${ }^{35}$. W pierwszym roku istnienia Sekcji wygłoszono aż 16 prelekcji (w programie znalazły się także wykłady poruszające tematykę spisko-orawską ${ }^{36}$ ). Przystąpiono ponadto do realizacji ambitnego przedsięwzięcia stworzenia bibliografii Podhala, Spisza i Orawy, zawierającej krótkie notatki poświęcone treści poszczególnych publikacji. Członkowie podzieleni na mniejsze zespoły opracowywali zagadnienia cząstkowe (zawiązano komisję ds. inwentaryzacji okazów kultury podhalańskiej, komisję badającą prawo zwyczajowe, a nawet komisję psychologiczną).

Do działania [...] zachęcała postawa i osobowość B. Piłsudskiego. Ten, dla ożywienia pracy sekcji, proponował poszczególnym członkom badania (tematy) indywidualne, zalecał organizowanie konkursów [...] np. na fotografie (budownictwo, wnętrza, typy ludzkie), opisy strojów, obrzędów itp. ${ }^{37}$

Z powodu wybuchu I wojny światowej nie doszedł do skutku konkurs na opis wybranego zwyczaju lub podania związanego z miejscowymi toponimami skierowany do nowotarskich gimnazjalistów.

Gdziekolwiek się pojawił, Bronisław zawierał znajomości z osobami gotowymi do bezinteresownego realizowania przedsięwzięć nakierowanych zarówno na kwestie naukowe, jak również dla dobra lokalnej ludności. Pierwsze sprawozdanie Sekcji Ludoznawczej informuje, że „zarząd uważał

${ }^{35}$ M.in. „O sposobach zbierania okazów etnograficznych dla Muzeum w Zakopanem” (B. Piłsudski) oraz „O sposobach badania współczesnej wsi polskiej” (Franciszek Bujak), Sprawozdanie Sekcyi Ludoznawczej..., s. XLII.

36 „Polacy na Spiżu” (Antoni Łukasiewicz), „Polacy i Węgrzy” (Adorján Divéky).

${ }^{37}$ Czesław Robotycki, Archiwalne materiaty ludoznawcze z teki redakcyjnej Juliusza Zborowskiego, „Rocznik Podhalański” 1979, t. 2, s. 173. 
za rzecz najpilniejszą nawiązanie stosunków z pokrewnymi Towarzystwami i instytucyami, oraz z osobami, mogącemi wziąć czynny udział w pracy nad etnografią Podhala"38. Pozyskiwał więc Piłsudski zastęp mniej lub bardziej zaangażowanych współpracowników, choć de facto cały ciężar pracy spoczywał na barkach przewodniczącego. Działalność Sekcji Ludoznawczej zamierała w okresie jego nieobecności ${ }^{39}$.

Próby przerwania momentów okresowej stagnacji podejmowała bliska współpracownica B. Piłsudskiego - Bronisława Giżycka ${ }^{40}$, „,najruchliwsza osoba w Sekcji [Ludoznawczej - przyp. KZ]”, jak określił ją Juliusz Zborowski ${ }^{41}$. Dzięki dysponowaniu znacznymi środkami finansowymi, stworzyła imponującą kolekcję góralskiego malarstwa na szkle (w ciągu pobytu na Podhalu pozyskała ok. 200 tego typu obiektów). „Nie żałując więc ni trudu ni pieniędzy, zaczęła jeździć po wsiach okolicznych zapuszczając się często i na Orawę, by zbierać te pogardzone obrazy i sprzęty z całem znawstwem i zamiłowaniem" - jak informuje poświęcone jej wspomnienie pośmiert$n \mathrm{e}^{42}$. Z inspiracji B. Piłsudskiego zajęła się pisaniem przyczynków etnograficznych, towarzyszyła mu również w jego spisko-orawskich wędrówkach. Podczas jednej z nich brat Marszałka miał okazję zetknąć się z orawskimi rzecznikami zbliżenia z Polską ${ }^{43}$. W latach 1912-1913 Giżycka weszła do zarządu Sekcji i zastępowała przewodniczącego w czasie jego zagranicznych wyjazdów. Zniechęcona postawą pozostałych nieaktywnych członków oraz problemami administracyjnymi starała się mimo wszystko kontynuować działalność aż do rozwiązania Sekcji Ludoznawczej w 1914 r.

${ }^{38}$ Sprawozdanie Sekcyi..., s. [XLI].

${ }^{39}$ Juliusz Zborowski, Z dziejów ludoznawstwa i muzealnictwa na Podhalu: Sekcja Ludoznawcza Towarzystwa Tatrzańskiego (1911-1919), „Rocznik Muzeum Etnograficznego w Krakowie" 1976, t. 6, s. 82.

${ }^{40}$ Bronisława Giżycka (ok. 1867-1921), właścicielka ziemska pochodząca z Podola, kolekcjonerka sztuki ludowej, ,,Kochany Wujaszku... "Listy Bronisława Pitsudskiego..., s. 40, przyp. 14 .

${ }^{41}$ Ibidem, s. 57.

42 „Gazeta Zakopiańska” 1921, nr 8, s. 3.

${ }^{43}$ Gościł u A. Divékiego - zaangażowanego społecznie historyka stosunków polsko-węgierskich, spotkał się z „,budzicielem” polskiej świadomości narodowej Aleksandrem Matonogiem, aptekarzem Eugeniuszem Sterculą i in. Krótki opis pobytu B. Piłsudskiego na Orawie przedstawił w liście do Juliusza Zborowskiego Stercula. Zob. Jerzy M. Roszkowski, Relacja Eugeniusza Sterculi o pobycie Bronisława Pitsudskiego na Orawie, „Literatura Ludowa" 1999, R. 43, nr 4-5, s. 131-133. 
Ważną, choć niezwiązaną z SLTT osobą, którą poznał B. Piłsudski podczas pobytu w Zakopanem, był doktor Jan Bednarski. Urodzony w Bystrej koło Jordanowa, bardzo wcześnie miał okazję zetknąć się z ludnością pogranicza. Ukończywszy studia lekarskie ${ }^{44}$, po kilkuletniej praktyce prowadzonej w Polsce i za granicą, przeplatanej doskonaleniem zawodowym, trafił w 1897 r. do Nowego Targu ${ }^{45}$.

Właśnie w tym mieście J. Bednarski rozwinął działalność polityczno-społeczną, która przyniosła mu tytuł honorowego obywatela. Zaraz po przybyciu do stolicy powiatu zapoczątkował nawiązywanie kontaktów z rodzącą się powoli warstwą nastawionej propolsko inteligencji Orawy ${ }^{46}$. Przy pomocy osób zaangażowanych w nielegalne dostarczanie polskich książek i prasy na tereny spisko-orawskie motywował do nauki języka literackiego. Ważną rolę odegrał również w toczącym się od początku XIX w. sporze o Morskie Oko.

Jan Bednarski doskonale rozumiał problemy młodzieży podejmującej naukę poza miejscem zamieszkania, sam bowiem uczył się w gimnazjum św. Anny w Krakowie, mając niezwykle skromne warunki bytowe ${ }^{47}$. Jako poseł na Sejm Krajowy, przez wiele lat zabiegał o utworzenie w Nowym Targu szkoły średniej. Zamierzenie to udało się w końcu zrealizować - we wrześniu 1904 r. młodzież z południa Galicji zyskała możliwość korzystania $\mathrm{z}$ edukacji ponadpodstawowej. Bednarski w swojej mowie inauguracyjnej podkreślił rolę placówki jako ośrodka kształtującego świadomość narodową:

Jeżeli teraz przypatrzymy się na kartę Galicyi, to zobaczymy, że powiat tutejszy wchodzi klinem w obce państwo z 3-ech stron z niem granicząc. Państwo to wprawdzie obce, lecz ludność naokół rdzennie polska.

Ludność ta biedna, zapomniana przez nas, uciskana przez rząd i wynaradawiona [!] przez madyarów, przez kościół i szkołę. Gimnazyum w N. Targu, z którego, mam nadzieję,

${ }^{44}$ Szerzej na temat edukacji J. Bednarskiego zob. Corpus Studiosorum Universitatis Iagiellonicae 1850-1918. A-D, red. Jerzy Michalewicz, Kraków 1999, s. 176.

${ }^{45}$ Jan Bednarski (1860-1926), lekarz, społecznik, poseł Sejmu Krajowego w Galicji, w latach 1919-1925 starosta powiatu spisko-orawskiego. Zob. Zygmunt Lasocki, Bednarski Jan, [w:] PSB, t. 1, Kraków 1935, s. 396-397.

${ }^{46}$ Cały rozdział poświęcił J. Bednarskiemu w swojej książce wspomnieniowej ks. Ferdynand Machay. Zob. Ferdynand Machay, Moja droga do Polski (pamiętnik), Kraków 1938, s. 47-59.

${ }^{47}$ Jerzy M. Roszkowski, Doktor Jan Bednarski-honorowy obywatel Nowego Targu, „Almanach Nowotarski” 1997, R. 1996, nr 1, s. 71. 
korzystać będzie, powinno nieść do niej kaganiec oświaty i uświadomienia narodowego. Z tej przyczyny, a mianowicie ze względu na położenie gimnazyum w Nowym Targu można śmiało nazwać kresowem [podkreślenie J. Bednarskiego] ${ }^{48}$.

Po uruchomieniu gimnazjum, dostępnego także dla uczniów zamiejscowych, pojawił się problem ich zakwaterowania. Dlatego na początku grudnia 1904 r. zorganizowano Towarzystwo Bursy Gimnazjalnej im. św. Stanisława Kostki, gromadzące fundusze na budowę bursy oraz wspierające ubogich wychowanków. Towarzystwo ponosiło całkowity koszt utrzymania młodzieży z terenów Spisza i Orawy, co stanowiło wyraz polityki zmierzającej w kierunku uświadamiania narodowego tamtejszej ludności ${ }^{49}$. Bednarski otaczał młodzież z tych terenów szczególną opieką, płacąc z własnych funduszy za utrzymanie, korepetycje, odzież czy podręczniki szkolne. Nawet przebywając poza Nowym Targiem, troszczył się o los „kresowych” uczniów, o czym świadczy zachowana korespondencja ${ }^{50}$.

Nowotarski działacz znalazł się w gronie inicjatorów I Zjazdu Podhalan ${ }^{51}$, obok takich znanych osób, jak pisarz Władysław Orkan, rzeźbiarz Wojciech Brzega czy późniejszy generał Wojska Polskiego Andrzej Galica. Na spotkaniu połączono obchody 25-lecia pracy literackiej Kazimierza Przerwy-Tetmajera z manifestacją patriotyczną - odsłonięciem pomnika Władysława Jagiełły. Z kolei na II Zjeździe Podhalan, odbywającym się latem 1912 r., Bednarski dostrzegł nadarzającą się okazję do rozpropagowania kwestii spisko-orawskiej. Regionaliści podhalańscy zgodzili się na włączenie w akcję „,budzicielską" na Górnych Węgrzech, postulowano też utworzenie organu prasowego mającego obejmować swoją tematyką również sąsiadów zza południowej granicy. Trzeciego sierpnia obradowała specjalnie powołana Sekcja Spisko-Orawska omawiająca cele i kierunki działania, jakie stawiali sobie za zadanie krzewiciele polskości wśród częściowo już zesłowaczonej ludności góralskiej.

${ }^{48}$ Mowa posła p. Bednarskiego przy uroczystem otwarciu gimnazyum dnia 10/9 1904, [w:] Krótki rys zabiegów i usiłowań około utworzenia gimnazyum w Nowym Targu, Nowy Targ 1907, s. 38.

${ }^{49}$ Więcej na temat utworzenia gimnazjum i bursy w katalogu wystawy zob. Robert Kowalski, Łukasz Podolak, Dzieje Bursy Gimnazjalnej w dokumencie i fotografii utrwalone. Część pierwsza 1904-1945, Nowy Targ 2011.

${ }^{50}$ Zob. J. M. Roszkowski, ,Zapomniane Kresy”..., s. 116.

${ }^{51}$ Zjazd ten odbył się w Zakopanem w dniach 19 i 20 sierpnia 1911 r. 
Zjazd zaowocował powstaniem „Gazety Podhalańskiej”, która bardzo szybko stała się trybuną dla inteligencji zaangażowanej w sprawy regionu, a także dla samych mieszkańców - publikowano w niej bowiem listy czytelników pisane gwarą. Nie ograniczała się jedynie do lokalnej problematyki, prezentując równocześnie bieżące wydarzenia z podzielonego zaborami kraju oraz z zagranicy. „Miała szeroki zasięg dzięki licznym echom i polemikom w prasie węgierskiej i słowackiej"52. Jej redaktorem został Feliks Gwiżdż ${ }^{53}$, publicysta znany z artykułów zamieszczanych w „Kurierze Lwowskim". Kierunek polityki narodowościowej prowadzonej na łamach tygodnika zaaprobował III Zjazd Podhalan, odbywający się w 1913 r. w Czarnym Dunajcu. W wygłoszonym wówczas przemówieniu Gwiżdż podkreślił zasługi posła Bednarskiego (faktycznego pomysłodawcy „Gazety"54) oraz innych, niewymienionych z nazwiska działaczy, dzięki którym „ludność polska zaczyna podnosić oczy i ten, który wczoraj jeszcze mówił, że Słowiok, dziś zaczyna się czuć bratem Podhalanina, góralem o poczuciu narodowem polskiem"55.

Pomoc dla Spisza i Orawy (głównie w dziedzinie oświaty) organizowały także lokalne koła Towarzystwa Szkoły Ludowej (dalej: TSL). Najprężniej działało, założone w 1894 r., Koło TSL w Zakopanem. Od 1910 r. podhalańskie koła były zrzeszone w mającym siedzibę w Nowym Targu Związku Okręgowym TSL. Dla lepszej koordynacji działań różnych grup zainteresowanych de facto tą samą tematyką regionaliści zakopiańscy zaproponowali zawiązanie Komitetu Spisko-Orawskiego. Dyskutowano na ten temat podczas walnego zjazdu kół Okręgowego Związku Towarzystwa w kwietniu 1914 r. Do zaproszonych gości należeli także J. Bednarski oraz B. Piłsudski, co świadczy o docenieniu przez władze TSL wkładu ostatniego z wymienionych w kwestię spisko-orawską.

${ }^{52}$ Marcin Jagła, Źródła zainteresowania polskiej opinii publicznej losami mieszkańców Spisza i Orawy przed pierwszą wojna światowa, „Almanach Nowotarski” 1999, R. 1998, s. 51.

${ }^{53}$ Feliks Gwiżdż (1885-1952), dziennikarz, pisarz, tłumacz z języka słowackiego, oficer Legionów. Był współzałożycielem oraz pierwszym redaktorem „Gazety Podhalańskiej”. Zob. Marek Gałęzowski, Senator z Podhala, „Biuletyn Instytutu Pamięci Narodowej” 2010, nr 1-2, s. 120-126.

${ }^{54}$ Był autorem uchwały w sprawie powołania czasopisma.

55 „Gazeta Podhalańska” 1913, nr 34, s. 2. 
Bednarski został - podobnie jak B. Piłsudski - niesłusznie skazany na zapomnienie. Ogrom osiągnięć tego zagorzałego „budziciela” polskości nakreślił, w tonie niezwykle emocjonalnym, Orawianin ks. Ferdynand Machay. Podsumowując zasługi zmarłego, pisał w artykule zamieszczonym w „Gazecie Podhalańskiej”:

[...] śp. Dr. Bednarski był czułym ojcem, troskliwym opiekunem całego - rozszerzonego - Podhala. Co jest na Podhalu wielkiego, pożytecznego, Dr. J. Bednarski miał we wszystkiem swoją pracowitą rękę [...]. Rzuć okiem gdzie chcesz: czy na kolej Nowy TargSucha, czy na Gimnazjum, czy na szpital, czy na Sokół, Bursę gimnazjalną, Kasę Oszczędności - niema [!] miejsca w Nowym Targu, któreby o jego pracy nie mówiło. [...] Patrz, zaglądnij do serc uświadomionych Polaków na Spiszu i Orawie, ich ból, ich zmartwienie przewyższa wszelkie, bo przeczuwają, że tego zapomnianego ludu polskiego nikt już tak nie pokocha jak on $[\ldots]^{56}$.

Podczas pobytu na Podhalu Piłsudski zaangażował się w sprawę budowy nowej siedziby Muzeum Tatrzańskiego. Historia tej placówki jest ściśle związana z Towarzystwem Tatrzańskim, w którego sprawozdaniu za lata 1873-1876 znajduje się wzmianka o utworzeniu w Kuźnicach muzeum, gdzie prezentowano okazy fauny i flory tatrzańskiej ${ }^{57}$. Dopiero w 1884 r., po latach stagnacji, rozpoczęto starania o zorganizowanie stałej ekspozycji. W tym celu powołano Towarzystwo Muzeum Tatrzańskiego im. dr. Tytusa Chałubińskiego w Zakopanem. Kolekcję pozyskiwaną głównie dzięki prywatnym darczyńcom umieszczono w domu Krzeptowskich przy ulicy Krupówki. Uroczyste otwarcie miało miejsce 1 lipca 1889 r. Kolejna zmiana nastąpiła w 1892 r., gdy Muzeum przeniosło się do drewnianego budynku przy ulicy Chałubińskiego. W artykułach z początku XX stulecia sygnalizowano ubóstwo działu etnograficznego, wymagającego pilnego uzupełnienia z powodu postępującego w szybkim tempie zaniku możliwości pozyskania materialnych świadectw kultury ludowej ${ }^{58}$. Ze względu na stale powiększające się zbiory rozpoczęto starania o budowę murowanego gmachu. Głównym projektantem został Stanisław Witkiewicz. Jego ideą było zaaranżowanie obiektu w tzw. ,stylu zakopiańskim”.

${ }^{56}$ Ferdynand Machay, Nad mogita ś.p. Dra Jana Bednarskiego, „Gazeta Podhalańska" 1926, nr 16, s. 1-2.

${ }^{57}$ Wanda Jostowa, Muzeum Tatrzańskie, [w:] Zakopane. Czterysta lat dziejów, t. 2, red. Renata Dutkowa, Kraków 1991, s. [431-]432.

${ }^{58}$ Ibidem' s. 435. 
Piłsudski natomiast zdawał sobie sprawę z faktu, iż wznoszony budynek nie spełnia optymalnych funkcji muzealnych. Nie było w nim bowiem pomieszczeń magazynowych, pokoi na pracownie naukowe, brakowało odpowiednio zaprojektowanych sal ekspozycyjnych ${ }^{59}$.

W trosce o należytą organizację kolekcji etnograficznej B. Piłsudski wydał memoriał pt. „W sprawie Muzeum Tatrzańskiego. (O urządzeniu działu ludoznawczego)" "60, stanowiący wykład nowoczesnego - jak na owe czasy wystawiennictwa. Wykorzystał w nim swoje doświadczenia muzealnicze zdobyte podczas zesłania ${ }^{61}$ oraz przy okazji licznych podróży po Europie, a także czasowych pobytów w Stanach Zjednoczonych i Japonii. Rozległą znajomość literatury przedmiotu zaprezentował w zestawieniu bibliograficznym kończącym omawiany tekst. Za niezbędne działanie uznał ścisłą selekcję przyszłych muzealiów przed ich włączeniem do właściwej kolekcji. Postrzegał muzeum jako wszechstronną placówkę naukowo-badawczą zaangażowaną w życie regionu, co przywodzi na myśl proponowaną współcześnie koncepcję muzeum partycypacyjnego ${ }^{62}$. Pewne novum stanowił niewątpliwie punkt dotyczący wykorzystania fonografu do nagrywania materiału etnograficznego ${ }^{63}$, a także wzbogacenia ekspozycji efektami dźwiękowymi.

Wszechstronność działalności B. Piłsudskiego na Podhalu doskonale obrazują jego starania o wydawanie czasopisma regionalnego. „Rocznik Podhalański" - bo taką nazwę nadano periodykowi - był pomyślany nie tylko jako organ Muzeum Tatrzańskiego, ale także innych instytucji działających na rzecz Zakopanego i okolic ${ }^{64}$. Planowano, że na jego łamach publikowane będą teksty dotyczące szeroko pojętej góralszczyzny, pisane

${ }^{59}$ Hanna Błaszczyk-Żurowska, Działalność kolekcjonerska..., s. 139.

${ }^{60}$ Tekst został opublikowany w pierwszym tomie „Rocznika Podhalańskiego” już po śmierci B. Piłsudskiego.

${ }^{61}$ Przyczynił się m.in. do organizacji muzeum w Aleksandrowsku na Sachalinie, gromadził eksponaty dla placówek w Chabarowsku i Błagowieszczeńsku. W latach 1899-1901 zajmował stanowisko pracownika merytorycznego w muzeum we Władywostoku.

${ }^{62}$ Stanisława Trebunia-Staszel, Muzeum Tatrzańskie jako laboratorium dziedzictwa. Część I, "Journal of Urban Ethnology” 2018, nr 16, s. 226.

${ }^{63}$ Dokumentowania muzyki góralskiej podjął się, zainspirowany przez Piłsudskiego, późniejszy długoletni dyrektor Muzeum Tatrzańskiego Juliusz Zborowski. Zob. Juliusz Zborowski, Wspomnienia I, „Ziemia. Ilustrowany miesięcznik krajoznawczy” 1934, nr 1-2, s. 5-9.

${ }^{64}$ Towarzystwa Szkoły Ludowej, Sekcji Ludoznawczej Towarzystwa Tatrzańskiego itd. 
zarówno przez naukowców, jak i przez samych górali ${ }^{65}$. Te ostatnie miały dostarczyć materiały źródłowe dla przyszłych naukowych przyczynków i badań etnograficznych. Prace nad „Rocznikiem” wstrzymano z powodu wybuchu I wojny światowej.

Jak już wcześniej wspomniano, zainteresowania badawcze B. Piłsudskiego nie ograniczały się jedynie do polskiego Podtatrza. Podczas licznych wędrówek górskich zetknął się z ludnością Spisza i Orawy. Uzupełniając kolekcję Muzeum Tatrzańskiego, nie zapomniał o pozyskaniu cennych z ludoznawczego punktu widzenia przedmiotów pochodzących z różnych obszarów Górnych Węgier ${ }^{66}$. W zamierzeniu pomysłodawcy „Rocznik Podhalański” miał być poświęcony także tematyce spisko-orawskiej, która znajdowała się w sferze zainteresowań redaktora naczelnego dziennika „Kurier Lwowski”.

Bolesław Wysłouch (1855-1937), bo o nim mowa, urodzony na Polesiu polski szlachcic o litewskich korzeniach ${ }^{67}$, pochodził - podobnie jak B. Piłsudski - z rodziny zaangażowanej w działalność patriotyczną ${ }^{68}$. Po ukończeniu studiów w Petersburgu, gdzie zetknął się z ideami ruchu narodnickiego ${ }^{69}$, powrócił do Królestwa Polskiego. Wkrótce został aresztowany za działalność socjalistyczną i osadzony w X Pawilonie Cytadeli Warszawskiej. Socjalizm w wydaniu Wysłoucha miał zabarwienie narodo$\mathrm{we}^{70} \mathrm{~W}$ przeciwieństwie do kosmopolityzmu wyznawanego przez większość

${ }^{65} \mathrm{~W}$ pierwszym tomie „Rocznika” miały znaleźć się dwa artykuły autorstwa Eugeniusza Sterculi dotyczące medycyny ludowej i zwyczajów żywieniowych mieszkańców Jabłonki na Orawie.

${ }^{66}$ Sekcja pozyskała 14 eksponatów z Orawy i 2 ze Spisza.

${ }^{67}$ Jego matka, Adela Gedroyć, wywodziła się z Litwy.

${ }^{68} \mathrm{Za}$ udzielenie poparcia dla powstania styczniowego rodzina została ukarana konfiskatą majątku.

${ }^{69}$ Narodnicy - zwolennicy obalenia caratu w Rosji; ruch głoszący hasła antyfeudalne, postulujący wprowadzenie socjalizmu agrarnego. Podczas pobytu w Petersburgu Wysłouch był związany z socjalizującymi organizacjami popierającymi program Narodnej Woli, której członkowie w 1881 r. przeprowadzili udany zamach na cara Aleksandra II. Zob. Bernard Szapiro, Tadeusz Rechniewski (1862-1916), Warszawa 1957, s. 18. Sześć lat później B. Piłsudski został skazany w procesie tzw. Frakcji Terrorystycznej Narodnej Woli za udział w zamachu na cara Rosji Aleksandra III. Więcej na ten temat zob. Pierwszy marca 1887 roku. Wspomnienia Józefa Łukaszewicza, wyd. Stefan Bergman, Warszawa, 1981.

${ }^{70}$ Peter Brock, Bolesław Wysłouch (1855-1937), „,Rocznik Dziejów Ruchu Ludowego" 1963 , nr 5, s. 402. 
rosyjskich socjalistów. Główną bowiem troską zaangażowanych społecznie polskich rewolucjonistów było dążenie do odzyskania niepodległości, co nie leżało w sferze zainteresowania Rosjan ${ }^{71}$.

Po wyjściu z więzienia ożenił się z Marią z Bouffałów ${ }^{72}$, która wkrótce stała się zaangażowaną działaczką ruchu ludowego, czynnie wspierającą pracę męża. Ze względu na niegościnną atmosferę, jaka panowała w zaborze rosyjskim, młode małżeństwo postanowiło w $1884 \mathrm{r}$. przenieść się do Galicji, by kontynuować działalność społeczną. Szczególną opieką otoczyli mieszkańców terenów wiejskich. B. Wysłouch wspomina:

Urodziłem się i wychowywałem na wsi, a więc od dzieciństwa przyglądałem się życiu pracowitego ludu wiejskiego i pokochałem ten lud serdeczny. Później, kiedy zacząłem się uczyć zrozumiałem, że najpierwszym obowiązkiem człowieka jest obrona uciśnionych przed krzywdą i praca nad ich podźwignięciem [...], zrozumiałem, że najpierwszym obowiązkiem Polaka jest praca dla Polski wolnej i szczęśliwej, więc dla dobra milionów polskiego ludu, który tyle przecierpiał $[\ldots]^{73}$.

Porównywalną postawę wobec syberyjskich autochtonów prezentował Bronisław Piłsudski.

Wysłouchowie od 1889 r. redagowali „Przyjaciela Ludu” - czasopismo skierowane przede wszystkim do czytelnika wiejskiego ${ }^{74}$. Prezentowało ono inną niż dotychczasowe pisma o podobnej tematyce formułę: było dalekie od klerykalizmu, a współtworzyć je mieli odbiorcy poprzez nadsyłanie do redakcji gotowych do publikacji listów czy utworów literackich pisarzy wywodzących się z ludu. Za główny cel stawiano uświadomienie polityczne polskiej wsi. Prezentowano postulaty ruchu ludowego przy jednoczesnym dążeniu do popularyzacji literatury pięknej oraz historii Polski (na tym polu, z dużym powodzeniem, działała Wysłouchowa).

Teoretycznymi zagadnieniami ruchu ludowego w Galicji zajmowały się dwa inne periodyki redagowane przez Wysłoucha. Pierwszy to „Przegląd

${ }^{71}$ B. Piłsudski, którego mariaż z socjalizmem rozpoczął się dość wcześnie i zakończył zesłaniem na Syberię, reprezentował takie samo stanowisko jak Wysłouch.

72 Maria Wysłouchowa (1858-1905), nauczycielka, działaczka społeczna, redaktorka czasopism przeznaczonych dla ludu, rzeczniczka równouprawnienia kobiet, Stownik biograficzny działaczy ruchu ludowego (makieta), Warszawa 1989, s. 447.

${ }^{73}$ Cyt. za P. Brock, Bolesław Wystouch..., s. 402.

${ }^{74}$ Szerzej na temat zaangażowania pary w pisarstwo przeznaczone dla czytelników rekrutujących się z warstw chłopskich zob. Jerzy Myśliński, Wysłouchowie - twórcy prasy ludowej, „Kwartalnik Historii Prasy Polskiej” 1991, t. 30, nr 3-4, s. [145-]152. 
Społeczny", na którego łamach publikowali działacze socjalistyczni (m.in. Bolesław Limanowski), drugi - „Kurier Lwowski”. O ile żywot „Przeglądu Społecznego” był dość krótki ${ }^{75}$, o tyle „Kurier Lwowski” wychodził aż do 1935 r. Dziennik ten związany ideowo z ruchem ludowym nie zaniedbywał tematyki społeczno-kulturalnej.

Właśnie dla „Kuriera” Piłsudski pracował jako korespondent zagraniczny podczas podróży po Europie. Świadczą o tym materiały zachowane w bibliotece Zakładu Narodowego im. Ossolińskich ${ }^{76}$. W liście z 27 września 1909 r. informuje Wysłoucha: „O sprawach polskich nie śmiem pisać, bo jeszcze muszę temu się przyjrzeć i dużo rzeczy się nauczyć. Mam zamiar, jak mówiłem Panu, opisać to, co się znajduje w muzeach ${ }^{77}$ paryskich polskiego"78. W tym samym liście prosi również o oficjalne poświadczenie bycia korespondentem gazety, co ułatwiłoby mu zbieranie materiałów do kolejnych artykułów.

Podczas pobytu za granicą Piłsudski odwiedził liczne muzea etnograficzne nie tylko w Paryżu, ale także w Wiedniu czy Pradze. Pisał wówczas kroniczki naukowe i przesyłał je Wysłouchowi do akceptacji. W kręgu jego zainteresowań nadal pozostały sprawy Dalekiego Wschodu, głównie Japonii, gdzie został serdecznie przyjęty przez tamtejszą inteligencję. Nie trafiały one - jak wynika z korespondencji - w gusta czytelników „Kuriera”79.

Sachaliński tułacz oraz lider ludowców - obaj jako członkowie Towarzystwa Ludoznawczego - współpracowali również na rzecz zorganizowania Wystawy Etnograficznej we Lwowie. Bezskutecznie próbowali pozyskać dla tej idei paryską Polonię. Mimo deklarowanego poparcia sporej liczby osób (w tym Stefana Żeromskiego i Władysława Mickiewicza), a także zawiązania odnośnego Komitetu, wystawa ostatecznie nie doszła do skutku.

Stosunek obu mężczyzn trudno określić mianem przyjaźni, jednak Piłsudski zwierzał się Wysłouchowi ze swoich problemów osobistych. Listy do „Czcigodnego Redaktora" mają zawsze ton pełen szacunku, ale jednocześnie szczerej sympatii. Brat Marszałka angażował się chętnie w inicjatywy

${ }^{75}$ Ukazywał się od stycznia 1886 do lipca $1887 \mathrm{r}$.

${ }^{76} \mathrm{ZNiO}$, Korespondencja Bolesława Wysłoucha z lat 1890-1937. Listy od różnych osób, sygn. 7181/II. s. 471-489.

${ }^{77}$ W oryginale: ,w muzeumach”.

${ }^{78} \mathrm{ZNiO}$, Korespondencja Bolesława Wysłoucha z lat 1890-1937. Listy od różnych osób, sygn. 7181/II, s. 471.

${ }^{79}$ Ibidem. 
podejmowane przez środowisko lwowskie ${ }^{80}$, publikował we wspomnianym już „Kurierze Lwowskim” czy czasopiśmie „Lud” redagowanym przez Adama Fischera. W kręgu jego zainteresowań znajdowały się sprawy dotyczące tzw. „Południowych Kresów”, które zajmowały również Wysłoucha ${ }^{81}$. Redaktor świetnie orientował się w sytuacji Słowian zamieszkujących ziemie wchodzące w skład Monarchii Austro-Węgierskiej, m.in. dzięki żonie Marii, która brała czynny udział w inicjatywach mających na celu edukację wsi polskiej, a także mieszkańców pogranicza (publikowała w „Ludzie” spisane w Zakopanem opowieści góralskie, utrzymywała też trwający niemal do końca życia kontakt z pisarzem Władysławem Orkanem). Urządziła w stolicy Tatr zjazd kobiet, co dało jej okazję do zapoznania się z góralszczyzną ${ }^{82}$.

Piłsudski, niepewny swoich naukowych kompetencji ${ }^{83}$, kontaktował się - zazwyczaj korespondencyjnie - z członkami środowiska akademickiego, m.in. z Kazimierzem Nitschem, Janem Michałem Rozwadowskim czy etnografem Edmundem Kołodziejczykiem ${ }^{84}$, wspomnianym w liście do Wysłoucha badaczem karpackiego pogranicza kulturowego. Bronisław zamierzał zwrócić się do niego z prośbą o wygłoszenie odczytu poświęconego tematyce spiskiej lub zorganizowanie tematycznej wycieczki popularnonaukowej ${ }^{85}$. Materiały zachowane w Archiwum Narodowym w Krakowie świadczą, że Kołodziejczyk korespondował z przedstawicielami Związku Przyjaciół Ludu Tatrzańskiego, planował nawet założyć filię Towarzystwa w Krakowie ${ }^{86}$.

${ }^{80}$ Gdy Bronisław związał się z Marią Żarnowską, przyjaciółką z lat młodzieńczych, postanowili razem zamieszkać we Lwowie (pozostali tam niemal cały 1908 r.). Z lokalną inteligencją zapoznał go prawdopodobnie Benedykt Dybowski (1833-1930), z którym korespondował jeszcze podczas zesłania na Sachalinie.

${ }^{81}$ Zob. J. M. Roszkowski, „Zapomniane Kresy”..., s. 171 i 174.

${ }^{82}$ Zob. Dioniza Wawrzykowska-Wierciochowa, Wystouchowa. Opowieść biograficzna, Warszawa 1975, s. 319-343.

${ }^{83}$ Nie ukończył rozpoczętych w Petersburgu studiów wskutek zesłania na Sachalin.

${ }^{84}$ Edmund Kołodziejczyk (1888-1915), slawista, etnograf; twórca „Bibliografii Słowianoznawstwa polskiego". Był współzałożycielem Towarzystwa Słowiańskiego w Krakowie oraz (podobnie jak B. Piłsudski) członkiem Towarzystwa Ludoznawczego we Lwowie. Publikował w „Świecie Słowiańskim”, „Kurierze Lwowskim”, „Ludzie” etc. Badacz osadnictwa polskiego na Spiszu, Orawie i Rusi Zakarpackiej. Zajmował się problemami madziaryzacji i słowakizacji kresowej ludności polskiego pochodzenia.

${ }^{85}$ Zob. publikowany list.

${ }^{86}$ Zob. listy skierowane do Antoniego Łukasiewicza, ANK, Organizacje społeczne zbiór szczątków zespołów, sygn. 29/575/4, k. 17-19, 27-29. 
Związek Przyjaciół Polskiego Ludu Tatrzańskiego (dalej: ZPPLT) powstał w 1911 r. we Lwowie. Przewodniczył mu geograf, pedagog i działacz społeczny Stanisław Majerski ${ }^{87}$ (1852-1926). Mimo dość mylącej, sugerującej zainteresowanie sprawami górali tatrzańskich nazwy, stowarzyszenie miało na celu prowadzenie wszechstronnej działalności wśród ludności zamieszkującej tereny Górnych Węgier.

Szeroko zakrojony program ZPPLT zakładał szereg akcji oświatowych, obejmujących tworzenie czytelni polskich, domów ludowych etc. na Spiszu i Orawie, a także transfer młodzieży „kresowej” do Galicji w celu jej kształcenia, co sprzyjało powstaniu nowego pokolenia uświadomionej narodowo inteligencji polskiej. B. Piłsudski w liście do Wysłoucha dostrzegł możliwe negatywne konsekwencje nauki zamiejscowej: „Kilku Spiżaków uczy się w gimnazjum w Nowym Targu, co jednak według mnie jest ryzykowną rzeczą, bo tacy potem postarają się uciec ze swej smutnej dzielnicy do centru[m] więcej kulturalnego". Dla zapobieżenia tego typu sytuacjom, warunkiem otrzymania wsparcia $\mathrm{w}$ edukacji miał być powrót stypendysty w rodzinne strony.

Kolejny postulat programu dotyczył podjęcia kroków w kierunku utworzenia polskiego biskupstwa na Węgrzech. Katolicka ludność Spisza i Orawy ulegała postępującej słowakizacji z powodu słowackojęzycznych księży pełniących posługę kapłańską na tych terenach. Protestantyzm wyznawany przez Madziarów nie zyskał zwolenników wśród kresowych górali.

Związek dążył także do nawiązania współpracy z różnymi organizacjami mogącymi go wesprzeć w działaniach „budzicielskich”. Ze względu na spore oddalenie Lwowa od rzeczonych terenów próbowano porozumieć się z bliżej rezydującymi oddziałami Towarzystwa Szkoły Ludowej w Krakowie, Nowym Targu, Piwnicznej czy Nowym Sączu. Sekcja organizacyjna Związku miała za zadanie tworzenie filii ZPPLT w miejscowościach przygranicznych.

Brak dowodów na to, że zakładana w programie działalność Związku znalazła jakikolwiek większy odzew ze strony społeczeństwa. Na podstawie zachowanych w Archiwum Narodowym w Krakowie materiałów można przypuszczać, że ograniczyła się do rozprowadzania publikacji w języku polskim oraz tworzenia bibliotek wespół z TSL.

${ }^{87}$ Zob. Zdzisław Kosiek, Majerski Stanisław, [w:] PSB, t. 19, Kraków 1974, s. $171-172$. 
Już 3 maja 1912 r. - czyli zanim skierował swój list do B. Wysłoucha B. Piłsudski napisał do Zarządu ZPPLT, anonsując gotowość Sekcji Ludoznawczej do współpracy ${ }^{88}$. Podkreślał w nim zainteresowanie oraz troskę SLTT o ,zaniedbane obszary” Spisza i Orawy, a także wyraził chęć zorganizowania wspólnych wycieczek naukowych. W załączniku korespondencji wyszczególnił czternaście osób zgłaszających akces na członków lwowskiego Towarzystwa (lista nieznacznie różni się od spisu przesłanego redaktorowi „Kuriera”) wraz z notatką o zebranych 28 koronach wpisowego.

Przez szereg lat Bronisław pozostawał w cieniu swojego brata Józefa. Dopiero współcześnie, dzięki licznym publikacjom i konferencjom międzynarodowym, odkrywamy wartość spuścizny, którą po sobie pozostawił. Działał na rozmaitych płaszczyznach: angażował się bezinteresownie w inicjatywy społeczne (zarówno podczas zesłania na Sachalinie, jak również w czasie kilkuletniego pobytu na Podhalu), prowadził badania etnograficzne, tworzył teksty na tematy muzealnicze, szkolił przyszłych badaczy kultury ludowej, był inicjatorem czasopisma „Rocznik Podhalański” etc.

Korespondował z wieloma osobami, podejmując (najczęściej zwieńczone sukcesem) próby zjednania ich dla własnych idei. Współpraca z B. Wysłouchem, z którym notabene łączy go wiele podobieństw biograficznych, pozwoliła mu nie tylko na poprawę sytuacji materialnej (pisał odpłatne artykuły do „Kuriera Lwowskiego”), ale także na włączenie się w akcję uświadomienia narodowego ludności Spisza i Orawy. Program stworzonej przez niego Sekcji Ludoznawczej obejmował obszar „Zapomnianych Kresów”, dlatego nawiązał kontakt z ZPPLT, licząc na współdziałanie obu instytucji.

Publikowany tekst obrazuje jeszcze jedną, mało znaną, kartę z życia B. Piłsudskiego. Daje też nadzieję na kolejne niespodziewane odkrycia epistolograficzne, które - być może - przyczynią się do powstania pełnej biografii tego niezwykłego człowieka, nazwanego niegdyś „królem Ajnów”.

$$
* \quad * \quad *
$$

Umieszczony w aneksie list zachował się w aktach Związku Przyjaciół Polskiego Ludu Tatrzańskiego (sygn. 29/575/4, k. 31-32). Materiały dotyczące tej organizacji trafiły do ówczesnego krakowskiego Wojewódzkiego Archiwum Państwowego w Krakowie jesienią 1953 r. za pośrednictwem

${ }^{88}$ Brudnopis listu znajduje się w archiwum Muzeum Tatrzańskiego, MT, Akta SL TT, sygn. AR/164 , k. 52-53 (list B. Piłsudskiego do Zarządu Towarzystwa Przyjaciół Ludu Tatrzańskiego we Lwowie, Zakopane 3 V 1912). 
Wojewódzkiego Archiwum Państwowego w Łodzi. Jednostka, jak można się domyślać po niewielkiej objętości oraz treści, nie obejmuje kompletu dokumentacji wytworzonej przez aktotwórcę. Zawiera liczne egzemplarze „Programu działania...”, fragmenty korespondencji osób związanych z akcją ,,budzicielską" na Spiszu i Orawie, a także omawiany tu list B. Piłsudskiego do B. Wysłoucha.

Ingerencja $\mathrm{w}$ treść rękopisu została zredukowana do minimum. Zachowano właściwy B. Piłsudskiemu styl i charakterystyczną dla niego składnię, natomiast poprawiono ewidentne błędy ortograficzne, uzupełniono interpunkcję, rozwinięto zastosowane przez autora skróty (nadawca listu skraca w tekście wyrazy „towarzystwo” oraz „tatrzańskie”). Miejscami zmodernizowano pisownię (np. „tym” zamiast ,tem”, ,głębokim” zamiast „głębokiem”); pozostawiono natomiast archaiczną obecnie formę wyrazu „Spisz” w występujących odmianach.

\section{ANEKS \\ [List Bronisława Pilsudskiego do Bolesława Wysłoucha z dnia 24.05.1912 r. $]^{89}$}

Towarzystwo Tatrzańskie

24 maja 1912

Sekcya Ludoznawcza

Zakopane

Dworzec Tatrzański ${ }^{90}$

\section{Szanowny i Kochany Panie \\ Redaktorze $^{91}$,}

Nie miałem czasu napisać panu uprzednio w sprawie zawiązanego tam we Lwowie Związku Przyjaciół Ludu Tatrzańskiego. Podniosłem tę sprawę na jednym z posiedzeń naszej Sekcji Ludoznawczej Towarzystwa Tatrzańskiego i znalazłem poparcie ze strony

\footnotetext{
${ }^{89}$ ANK, Organizacje społeczne - zbiór szczątków zespołów, sygn. 29/575/4, k. 31-32.

${ }^{90}$ Siedziba sekcji.

${ }^{91}$ List zawiera dopisek: „Adresowany do WP. Wysłoucha”.
} 
12 osób. Złożyły one po 2 korony $^{92}$. Podaję ich nazwiska i adresy ${ }^{93}$. Pieniędzy nie przesyłam tymczasowo, bo może będzie lepiej zostawić je tu i zorganizować filię Towarzystwa, bo działalność bezpośrednia tu byłaby chyba większą. Do Zakopanego podążają i do lekarzy i z nabiałem mieszkańcy Spiżu w sporej ilości.

Mówiłem z Brzegą ${ }^{94}$, lecz ten czasowo się odmówił, bo należy do innego Towarzystwa Spiżowego $0^{95}$, które też coś robić zamierzało. Ja od innych też o tym słyszałem, i zamierzam nawet bliżej o to się rozpytać i dowiedzieć od Dra [słowo skreślone] Bednarskiego ${ }^{96} \mathrm{~W}$ Nowym Targu. Zamierzano wydać np. Kalendarz podhalski [sic!] dla wszystkich w okolicach Tatr zamieszkałych przydatny ${ }^{97}$.

Kilku Spiżaków [!] uczy się w gimnazjum w Nowym Targu - co jednak według mnie jest ryzykowną rzeczą, bo tacy potem postarają się uciec ze swej smutnej dzielnicy do centru[m] więcej kulturalnego.

Jeżeli będą dwie instytucje, to może to nic nie szkodzić, byle nie było drobnostkowego zwalczania się: współzawodnictwo jest dobre, lecz złe w skutki - rywalizacja połączona $\mathrm{z}$ niechęcią.

Powtarzam teraz prośbę o nadesłanie nam w ciągu lata kogoś przygotowanego do wygłoszenia odczytu o Spiżu ${ }^{98}$ (mam zamiar prosić E. Kołodziejczyka ${ }^{99}$, o ile go znajdę - bo on napisał większą pracę o tym ${ }^{100}$, i dla pokierowania wycieczką popularną rozliczaną na młodzież, w lecie bawiącą w Zakopanem i okolicach).

\footnotetext{
${ }^{92}$ Możliwe, że o tym skromnym funduszu pisze J. Zborowski w swoim artykule, omawiając działalność Sekcji Ludoznawczej: „Zaraz po swej kresowej wycieczce [Piłsudski - przyp. KZ] jedna też członków w Zakopanem [...] i przesyła Bednarskiemu od siebie i kilkunastu znajomych trochę grosza na akcję wśród węgierskich Polaków.”, J. Zborowski, Z dziejów ludoznawstwa ..., s. 44.

${ }_{93}$ Wspomniane osoby to: Aleksandra Juchno (ul. Krupówki), Julia Kratowska (ul. Przecznica), Olimpia Giżycka (ul. Sienkiewicza), Drowa Borain [prawdopodobnie Zofia de Beaurain] (ul. Zamoyskiego), Maria Hanicka (ul. Sienkiewicza), Bronisława Giżycka (ul. Sienkiewicza), Eugenia Wysocka (ul. Sienkiewicza), Bronisława Kondratowiczowa (ul. Skibówki), Antoni Mikulski (ul. Skibówki), Konrad Nikorowicz (brak adresu), Tadeusz Korniłowicz (Bystre), Bronisław Piłsudski (Dworzec Tatrzański), ANK, Organizacje społeczne - zbiór szczątków zespołów, sygn. 29/575/4, k. 33. List do ZPPLT przechowywany w Archiwum Muzeum Tatrzańskiego wymienia dodatkowo Elizę Mogilnicką oraz Gustawową Daniłowską, które prawdopodobnie zrezygnowały z członkostwa.

${ }^{94}$ Wojciech Brzega, zob. przyp. 24.

${ }^{95}$ Chodzi o „Koło Spiżowe” im. Klaudyny Potockiej, założone w Krakowie przez Juliana Jerzego Teisseyre. Jego członkowie działali na rzecz uświadomienia narodowego ludności Górnych Węgier w latach 1904-1914, zakładając biblioteki, przemycając za granicę polskie elementarze etc.

${ }^{96}$ Chodzi o doktora Jana Bednarskiego, zob. przyp. 37.

${ }^{97}$ Kalendarz został wydany nakładem Podhalańskiej Spółki Wydawniczej w 1913 r.

${ }^{98}$ Odbyły się dwa wykłady na ten temat, zob. przyp. 29.

${ }^{99}$ Biogram Kołodziejczyka zob. przyp. 80.

${ }^{100}$ Przypuszczalnie Piłsudskiemu chodziło o książkę: Edmund Kołodziejczyk, Ludność polska na Górnych Węrzech, Kraków 1910.
} 
Za przesłanie Kurjera serdecznie dziękuję. Obecnie wybrałem się na wycieczkę krótką po muzeach ${ }^{101}$ na węgierskiej stronie wzdłuż Tatr ${ }^{102}$.

Zawsze z głębokim poważaniem i przyjazny, Bronisław Piłsudski

\section{BIBLIOGRAFIA}

\section{Źródła rękopiśmienne}

Archiwum Narodowe w Krakowie

Związek Przyjaciół Polskiego Ludu Tatrzańskiego, sygn. 29/575/4.

Muzeum Tatrzańskie

Akta Sekcji Ludoznawczej Towarzystwa Tatrzańskiego, sygn. AR/164.

Zakład Narodowy im. Ossolińskich

Korespondencja Bolesława Wysłoucha z lat 1890-1937. Listy od różnych osób, sygn. $7181 /$ II.

\section{Źródla drukowane}

“Dear Father!” a collection of B. Pitsudski’s letters, et alii. Wyd. Koichi Inoue. Sapporo: Slavic Research Center Hokkaido University, 1999.

„,Kochany Wujaszku...” Listy Bronisława Piłsudskiego do Stanisława Witkiewicza. Oprac. naukowe Antoni Kuczyński. Zakopane: Muzeum Tatrzańskie im. dr. Tytusa Chałubińskiego, 2016.

Pierwszy marca 1887 roku. Wspomnienia Józefa Łukaszewicza. Wyd. Stefan Bergman. Warszawa: Państwowy Instytut Wydawniczy, 1981.

Statut Sekcyi Ludoznawczej Towarzystwa Tatrzańskiego. W: „Kochany Wujaszku...” Listy Bronisława Pitsudskiego do Stanisława Witkiewicza. Zakopane: Muzeum Tatrzańskie im. dr. Tytusa Chałubińskiego, 2016, s. 147-154.

\section{Prasa}

„Gazeta Podhalańska” 1913, nr 34.

„Gazeta Zakopiańska” 1921, nr 8.

„Kalendarz Podhalański na rok 1914”.

„Pamiętnik Towarzystwa Tatrzańskiego” 1913, t. 34.

\section{Opracowania}

[Bednarski Jan]: Mowa posła p. Bednarskiego przy uroczystem otwarciu gimnazyum dnia 10/9 1904. W: Krótki rys zabiegów i usiłowań około utworzenia gimnazyum w Nowym

${ }^{101} \mathrm{~W}$ oryginale „muzeumach” - forma zaczerpnięta z gwary podhalańskiej, por. Wojciech Brzega, Opowiadanie Jaśka Wirhowego o Ziemi świętej, „Kalendarz Podhalański na rok 1914” 1913, R. 1, s. 62.

${ }^{102}$ Pokłosiem tych wędrówek była pogadanka pt. „Wrażenia z wycieczki na Słowaczyznę”, wygłoszona w ramach odczytów realizowanych przez SLTT. 
Targu. [Nowy Targ]: nakładem Dyrekcyi C.K. Gimnazyum w Nowym Targu, 1907, s. 37-39.

Błaszczyk-Żurowska Hanna: Działalność kolekcjonerska Bronisława Piłsudskiego w Zakopanem. „Literatura Ludowa” s. 137-145.

Brock Peter: Bolesław Wysłouch (1855-1937). „Rocznik Dziejów Ruchu Ludowego” 1963, nr 5, s. 401-419.

Brzega Wojciech: Opowiadanie Jaśka Wirhowego o Ziemi świętej. „Kalendarz Podhalański na rok 1914" 1913, R. 1, s. 58-63.

Corpus Studiosorum Universitatis Iagiellonicae 1850-1918. A-D. Red. Jerzy Michalewicz. Kraków: cop. Archiwum Uniwersytetu Jagiellońskiego, 1999.

Dall Lesław: Józef Piłsudski w Zakopanem w latach 1901-1922. Kraków: Księgarnia Akademicka, 2019.

Dobrowolski Kazimierz: Powstanie świadomości narodowej u ludu polskiego na Spiszu i Orawie. „Przegląd Współczesny” 1922, R. 1, t. 3, s. 51-62.

Florkowska-Frančić Halina: Ostatnie lata Bronisława Piłsudskiego 1915-1918 (Szwajcaria-Paryż). W: Bronisław Pitsudski (1866-1918). Człowiek - uczony - patriota. Red. Mieczysław Rokosz [et al.]. Zakopane: Towarzystwo Muzeum Tatrzańskiego, 2003, s. $185-210$.

Gałęzowski Marek: Senator z Podhala. „Biuletyn Instytutu Pamięci Narodowej” 2010, nr 1-2, s. 120-126.

Jagła Marcin: Źródła zainteresowania polskiej opinii publicznej losami mieszkańców Spisza i Orawy przed pierwsza wojna światową. „Almanach Nowotarski” 1999, R. 1998, nr 3, s. 47-52.

Jostowa Wanda: Muzeum Tatrzańskie. W: Zakopane. Czterysta lat dziejów, t. 2. Red. Renata Dutkowa. Kraków: Krajowa Agencja Wydawnicza, 1991, s. 431-459.

Kołodziejczyk Edmund: O słowaczeniu i madiaryzacyi. „Świat Słowiański” 1913, R. 9, t. 2, nr 104-105, s. 464-474.

Kosiek Zdzisław: Majerski Stanisław. W: PSB, t. 19. Kraków: Polska Akademia Umiejętności, 1974, s. 171-172.

Kowalski Robert, Podolak Łukasz: Dzieje Bursy Gimnazjalnej w dokumencie i fotografii utrwalone. Część pierwsza 1904-1945. Nowy Targ: Towarzystwo Bursy Gimnazjalnej im. dr. Jana Bednarskiego w Nowym Targu, Polskie Towarzystwo Historyczne Oddział w Nowym Targu, 2011.

Kozak Anna: Zakopiańska kolekcja Bronisława Piłsudskiego. W: Ajnowie, górale i Bronisław Piłsudski. Red. Anna Król. Kraków: Muzeum Sztuki i Techniki Japońskiej Manggha, 2018, s. 175-183.

Kuczyński Antoni: Bronisław Piłsudski (1866-1918) zesłaniec i badacz kultury ludów Dalekiego Wschodu. „Niepodległość i Pamięć” 2005, 22/2 (50), s. 7-93.

Kuczyński Antoni: „Kochany Ojcze! Raz jeszcze pozwolono mi napisać do Ciebie... ”. Listy Bronisława Pitsudskiego. „Literatura Ludowa” 1999, R. 43, nr 4-5, s. 89-101.

Lasocki Zygmunt: Bednarski Jan. W: PSB, t. 1. Kraków: Polska Akademia Umiejętności, 1935, s. 396-397.

Machay Ferdynand: Moja droga do Polski (pamiętnik). Kraków: Drukarnia Przemysłowa w Krakowie, 1938. 
Machay Ferdynand: Nad mogiła ś.p. Dra Jana Bednarskiego. „Gazeta Podhalańska” 1926, nr 16, s. 1-2.

Myśliński Jerzy: Wysłouchowie - twórcy prasy ludowej. „Kwartalnik Historii Prasy Polskiej” 1991, R. 30, nr 3-4, s. 145-152.

Nitsch Kazimierz: Ze wspomnień językoznawcy. Kraków: Państwowe Wydawnictwo Naukowe, 1960.

Piłsudski Bronisław: Materials for the Study of the Ainu Language and Folklore. Cracow: Imperial Academy of Sciences, 1912.

Piłsudski Bronisław: W sprawie Muzeum Tatrzańskiego (O urządzeniu działu ludoznawczego). „Rocznik Podhalański” 1914-1921, t. 1, s. 147-188.

Radwańska-Paryska Zofia, Paryski Witold Henryk: Encyklopedia tatrzańska. Warszawa: Sport i Turystyka, 1973.

Robotycki Czesław: Archiwalne materiały ludoznawcze z teki redakcyjnej Juliusza Zborowskiego. „Rocznik Podhalański” 1979, t. 2, s. 171-177.

Roszkowski Jerzy M.: Doktor Jan Bednarski - honorowy obywatel Nowego Targu. „Almanach Nowotarski” 1997, R. 1996, nr 1, s. 71-79.

Roszkowski Jerzy M.: Relacja Eugeniusza Sterculi o pobycie Bronisława Pitsudskiego na Orawie. „Literatura Ludowa” 1999, R. 43, nr 4-5, s. 129-134.

Roszkowski Jerzy M.: ,Zapomniane Kresy”. Spisz, Orawa, Czadeckie w świadomości i działaniach Polaków 1895-1925. Nowy Targ: Powiatowe Centrum Kultury w Nowym Targu, 2018.

Semkowicz Władysław: Walka o polskie „kresy południowe”. „Orli Lot” 1924, R. 5, nr 2-3, s. 18-23.

Sieroszewski Wacław: Bronisław Piłsudski urodził się w roku 1866 w Zułowie w pow. Święciańskim, zmart w roku 1918 w Paryżu. ,Rocznik Podhalański” 1914-1921, nr 1, s. V-XXX.

Słownik biograficzny działaczy ruchu ludowego (makieta). Warszawa: Ludowa Spółdzielnia Wydawnicza, 1989.

Staszel Jan: Bronisław Pitsudski i jego zwiąki z Akademia Umiejętności w Krakowie. „Rocznik Biblioteki PAU i PAN w Krakowie” 2001, R. 46, s. 7-104.

Staszel Jan: Listy Bronisława Pitsudskiego do Juliana Talko-Hryncewicza z lat 1909-1914. „Rocznik Biblioteki Naukowej PAU i PAN w Krakowie” 2005, R. 50, s. 187-250.

Szapiro Bernard: Tadeusz Rechniewski (1862-1916). Warszawa: Książka i Wiedza, 1957.

Špiesz Anton: Dzieje Słowacji na drodze do uświadomienia narodowego. Bratislava: Vydavatels`tvo Perfekt, 1992.

Trebunia-Staszel Stanisława: Muzeum Tatrzańskie jako laboratorium dziedzictwa. Część I. "Journal of Urban Ethnology" 2018, nr 16, s. 217-231.

Urbańczyk Stanisław: Nitsch Kazimierz Ignacy. W: PSB, t. 23. Kraków: Polska Akademia Umiejętności, 1978, s. 145-150.

Urbańczyk Stanisław: Rozwadowski Jan Michał. W: PSB, t. 32. Kraków: Polska Akademia Umiejętności, 1989-1991, s. 406-409.

Wawrzykowska-Wierciochowa Dioniza: Wysłouchowa. Opowieść biograficzna. Warszawa: Ludowa Spółdzielnia Wydawnicza, 1975. 
Wójcik Zbigniew: O Borysie Wigilewie (komentarz do listu do Mieczystawa Limanowskiego). „Rocznik Podhalański” 1997, t. 7, s. 269-280.

Wójcik Zbigniew: Z nieznanej korespondencji zesłańczej Bronisława Pitsudskiego. „Niepodległość i Pamięć" 1996, nr 3/2 (6), s. 153-160.

Zborowski Juliusz: Wspomnienia I. „Ziemia. Ilustrowany miesięcznik krajoznawczy” 1934, nr 1-2, s. 5-9.

Zborowski Juliusz: Z dziejów ludoznawstwa i muzealnictwa na Podhalu: Sekcja Ludoznawcza Towarzystwa Tatrzańskiego (1911-1919). „Rocznik Muzeum Etnograficznego w Krakowie" 1976, t. 6, s. 35-115.

AUTOR: Karolina Zięba - archiwistka, Archiwum Narodowe w Krakowie; zainteresowania badawcze: historia XIX-wiecznej Europy, muzealnictwo, historia społeczna; e-mail: kzieba@ank.gov.pl

AUTHOR: Karolina Zięba - archivist, National Archives in Krakow; research interests: history of $19^{\text {th }}$-century Europe, museum studies, social history; e-mail: kzieba@ank.gov.pl 